\title{
Ti bud for behandling med psykofarmaka
}

\author{
Pasienter med psykiske lidelser blir ofte behandlet med kombinasjoner av legemidler som ikke har doku- \\ mentert effekt, i doser som ikke er anbefalt og på ikke-godkjent indikasjon. De behandles etter «behandlings- \\ praksis» og «klinisk skjønn», og oppfølgingen av den medikamentelle behandlingen er mangelfull. Dette \\ fører etter vår mening til at noen pasienter overbehandles og andre underbehandles, med påfølgende terapi- \\ svikt og bivirkninger.
}

\begin{abstract}
Du er på legevakten fordi du har vondt $i$ halsen. Etter å ha blitt undersøkt får du resept på et antibiotikum. En uke senere er $d u$ fortsatt like dårlig. Fastlegen din mener et nytt legemiddel vil fungere bedre og skriver ut dette i tillegg, siden det ikke kan utelukkes at du kunne vart enda verre uten det første legemidlet. Etter to uker med behandling er du heldigvis nesten frisk. Legen din vil likevel at du skal fortsette med begge legemidlene $i$ halv dose en stund til for å forebygge tilbakefall. I tillegg skriver han ut medisin mot virus, siden det ikke er helt sikkert at det var bakterier som gjorde deg syk.
\end{abstract}

Dette er ikke en sann historie. Leger i Norge skal ikke behandle infeksjoner på denne måten. Men dersom vi endrer litt på historien og bytter halsinfeksjon og antibiotika med psykisk lidelse og psykofarmaka, er den dessverre ikke like usannsynlig.

Det finnes lett tilgjengelige behandlingsanbefalinger for psykiske lidelser, og det er utarbeidet retningslinjer og indikasjoner for hvert enkelt legemiddel (1). Det finnes flere anbefalinger for god legemiddelbehandling $(2,3)$. Gjennom erfaring ved psykiatriske og farmakologiske avdelinger har vi sett at det likevel er vanlig å behandle pasienter med legemiddelkombinasjoner som ikke er dokumentert, i doser som ikke er anbefalt og på ikke-godkjent indikasjon. Vi ser dette daglig på rekvisisjonsskjemaer, i blodprøver og blant pasienter på psykofarmakologisk poliklinikk.

Psykiske lidelser er ofte kroniske, med et svingende forløp. Det finnes få biologiske tester som er relevante. Det er en utbredt praksis å stole på «klinisk skjønn» og «behandlingstradisjon». Pasienter med psykiske lidelser behandles også ofte med medisiner mot symptomer som smerter, uro, søvnvansker og fordøyelsesbesvær i tillegg til medisiner mot somatiske sykdommer. De kan derfor ende opp med et høyt forbruk av legemidler.

Når vi står overfor et problem som tilsynelatende ikke lar seg løse med de etablerte retningslinjene, er det lett å forsøke noe nytt - som å øke dosen, kombinere med nye legemidler og å gi legemidler mot bivirkningene som oppstår. Men pasienter med psykiske lidelser fortjener bedre enn behandling på prøve-og-feile-nivå. Psykofarmakologisk behandling bør følge de grunnleggende reglene for kvalitetsarbeid: planlegge, utføre, kontrollere og korrigere. Her er vårt forslag.

\section{De ti budene}

1. Du skal stille riktig diagnose og vite hvilken indikasjon du gir legemidlet på Riktig diagnose er en forutsetning for riktig behandling. Ikke alle pasienter med depresjonssymptomer skal ha antidepressiver, og ikke all engstelse er angst. Dersom behandlingen starter før en diagnose er stilt, vil dette kunnet påvirke forløpet slik at det blir vanskelig å stille korrekt diagnose og gi optimal behandling.

2. Du skal ha et mål for behandlingen Psykoterapi virker, og kontakt med en behandler vil bedre symptomene for de fleste pasienter. Du skal derfor ha et mål for legemiddelbehandlingen, og dette målet skal være annerledes enn naturlig forløp av lidelsen uten intervensjon. Dersom legemidler ikke vurderes å ha effekt utover sykdommens naturlige forløp eller samtaleterapi, se bud 6 .

\section{Du skal vite at du gir legemidlet i riktig} dose og med tilstrekkelig varighet Samme dose kan gi forskjellig effekt. Det er stor individuell variasjon i omsetning av legemidler. Doser som er effektive hos én pasient, kan gi bivirkninger eller terapisvikt hos en annen. Forskjeller i behandlingseffekt og forekomsten av bivirkninger kan ofte forklares av forskjeller i serumkonsentrasjon og konsentrasjon på virkestedet (4). Psykofarmaka har sammensatte virkningsmekanismer. Effekt er et resultat av rask binding på reseptornivå og mer langsomme intracellulære prosesser. Det tar derfor tid før effekten av et legemiddel kan vurderes.

\section{Du skal behandle én sykdom med ett lege- middel}

Kombinasjonsbehandling er blant de mest utbredte, men dårligst dokumenterte prinsippene i psykofarmakologien. Gunstig effekt av kombinasjonsbehandling er nesten aldri vitenskapelig dokumentert (5). Kombinasjonsbehandling øker faren for bivirkninger og nedsatt etterlevelse (6). Siden virkningsmekanismene til de enkelte legemidlene bare delvis er kjent, er det vanskelig å forutsi effekten av å kombinere ulike legemidler. Kombina- sjonsbehandling gjør det vanskelig å finne rett dose, vanskelig å vurdere effekten av doseendringer og vanskelig å vurdere årsaken til bivirkninger. Hvis det er behov for kombinasjonsbehandling, se bud 1 og bud 3 .

\section{Du skal ikke behandle legemiddelbivirk-} ninger med legemidler

Bivirkninger er vanlig. Alle psykofarmaka har bivirkninger, av varierende alvorlighetsgrad. Bivirkninger skal utredes nøye. De bør håndteres med kontroll av dose, vurdering av mulige interaksjoner eller bytte av legemidler. Å legge til nye legemidler gir risiko for nye bivirkninger, interaksjoner og tilvenning. Medisiner mot bivirkninger skal være siste utvei etter at andre tiltak har vært vurdert.

\section{Du skal seponere legemidler som ikke} har effekt

Mange pasienter ender opp med å bruke flere legemidler enn det er behov for. Dette kan skyldes at behandlingen har startet i en akutt situasjon med høy symptomintensitet, at de er satt på legemidler på feil grunnlag eller at det er utviklet toleranse. Det kan virke som om det er lettere å legge til nye legemidler når behandlingen svikter enn å seponere dem som ikke virker. Vi skal være kritisk til alle legemidler, og ved tvil bør prøveseponering under klinisk overvåking vurderes.

\section{Du skal giøre én endring om gangen} Det er lett å få det travelt i behandlingen av psykisk lidelse. Pasienten lider, avdelingslederen vil ha en rask utskrivning og de pårørende er fortvilet over at det ikke skjer nok. Dette fører til press om å gjøre noe, gjerne flere ting samtidig. Det kan være vanskelig å vurdere klinisk effekt og bivirkninger når behandlingen endres. Gjøres det flere endringer samtidig, blir det umulig å vite hvilke som har gitt effekt. To tiltak kan også motvirke hverandre i gass-brems-interaksjoner.

8. Du skal huske at sykdommen du behandler, ikke alltid er pasientens eneste sykdom

Ved psykiske lidelser er det ofte betydelig komorbiditet som kan påvirke og vanskeliggjøre behandlingen. Interaksjoner mellom legemidler kan gi terapisvikt eller 
bivirkninger. Grundig utredning og god kommunikasjon med pasienten og med andre behandlere er nøkkelen til god behandling.

9. Du skal huske at pasientene bruker legemidler og preparater de ikke forteller deg om

En rekke legemidler, også mot somatiske lidelser, har effekter og bivirkninger som kan minne om symptomer på psykiske lidelser. Pasienter forteller ikke alltid uoppfordret om bruk av andre legemidler (7). Naturlegemidler og kosttilskudd kan også gi alvorlige bivirkninger og interaksjoner. Det samme kan rusmidler. Det er derfor viktig å kartlegge all slik bruk.

\section{Du skal ikke behandle etter prøve-og- feile-metoden}

Prøving og feiling er en vanlig tilnærming ved psykofarmakologisk behandling. Dette øker risikoen for behandlingssvikt. For hvert mislykket behandlingsforsøk reduseres etterlevelsen og placeboeffekten. Gjør en grundig vurdering av effekt og bivirkninger ved tidligere legemiddelbruk. Undersøk også om det tidligere er gjort serumkonsentrasjonsmålinger og farmakogenetiske analyser. God planlegging av behandlingen øker sannsynligheten for å lykkes.

\section{Et råd med på veien}

Du skal vore kritisk og huske at behandlingstradisjoner ikke alltid er bygd på vitenskapelig dokumentasjon
Vær kritisk til etablert praksis. Er den vitenskapelig basert? Vær klar til å prøve nye behandlingsformer når ny kunnskap tilsier det. Ta hensyn til at forskningsresultater oftest er basert på store grupper pasienter.

Husker du at pasienten du behandler er unik når det gjelder bakgrunn, genetikk, sykdomsbilde og andre sykdommer, vil du ha et godt utgangspunkt for å kunne hjelpe.

\section{Dag Kristen Solberg}

dsolberg@mil.no

Helge Refsum

Dag Kristen Solberg (f. 1968) er spesialist

i psykiatri og i klinisk farmakologi. Han er psykiater og orlogskaptein i Forsvarets sanitet og tidligere seksjonsoverlege ved Senter for psykofarmakologi, seksjon psykofarmakologisk poliklinikk ved Diakonhjemmet Sykehus.

Forfatter har fylt ut ICMJE-skjemaet og oppgir ingen interessekonflikter.

Helge Refsum (f. 1947) er spesialist i klinisk farmakologi, dr.med. og professor. Han er avdelingsoverlege og leder for Senter for psykofarmakologi ved Diakonhjemmet Sykehus. Forfatter har fylt ut ICMJE-skjemaet og oppgir ingen interessekonflikter.

\section{Litteratur}

1. Statens legemiddelverk whw. legemiddelverket no (26.11.2014).

2. Glick ID, Balon RJ, Ballon J et al. Teaching pearls from the lost art of psychopharmacology. J Psychiatr Pract 2009; 15: 423-6.
3. Salzman C, Glick I, Keshavan MS. The 7 sins of psychopharmacology. J Clin Psychopharmacol 2010; 30: 653-5.

4. Murray M. Role of CYP pharmacogenetics and drug-drug interactions in the efficacy and safety of atypical and other antipsychotic agents. J Pharm Pharmacol 2006; 58: 871-85.

5. Glick ID, Pham D, Davis JM. Concomitant medications may not improve outcome of antipsychotic monotherapy for stabilized patients with nonacute schizophrenia. J Clin Psychiatry 2006; 67: 1261 -5

6. Hoffman DA, Schiller M, Greenblatt JM et al. Polypharmacy or medication washout: an old tool revisited. Neuropsychiatr Dis Treat 2011; 7 639-48.

7. Tveito M, Bramness JG, Engedal K et al. Psychotropic medication in geriatric psychiatric patients: use and unreported use in relation to serum concentrations. Eur J Clin Pharmacol 2014: 70 $1139-45$

Mottatt 19.9. 2014 og godkjent 26.11. 2014. Redaktør: Erlend Hem.

TR Engelsk oversettelse på www.tidsskriftet.no

Publisert først på nett. 